\title{
E-TOOL FOR DATA PROCESSING ACQUIRED FROM THE TRANSPORT DEVICE ON-BOARD RECORDER
}

\section{NARZĘDZIE DO PRZETWARZANIA DANYCH POZYSKANYCH Z REJESTRATORA POKLADOWEGO ŚRODKA TRANSPORTU}

\author{
Janusz Szpytko ${ }^{1}$, Pawel Hyla ${ }^{2}$ \\ (1,2) AGH University of Science and Technology \\ Akademia Górniczo-Hutnicza \\ Al. Mickiewicza 30, PL 30-059 Kraków \\ E-mails: (1) szpytko@agh.edu.pl (2) hyla@agh.edu.pl
}

\begin{abstract}
The paper is focusing on an e-tool for data processing acquired from the transport device on-board recorder. The developed e-tool is processing data related to the device exploitation parameters and movement trajectory that can be used to improve transport devices safety and reliability.
\end{abstract}

Keywords: Telematics, GPS, NMEA

Streszczenie. Przedmiotem publikacji jest sposób pozyskiwania oraz obróbka danych specjalistycznych, pozyskanych $\mathrm{z}$ modułu rejestrującego parametry eksploatacyjne i pozycjonowanie w przestrzeni roboczej użytkowanego mobilnego środka transportu, dla potrzeb bezpieczeństwa i niezawodności.

Słowa kluczowe: Telematyka, GPS, NMEA 


\section{E-TOOL FOR DATA PROCESSING ACQUIRED FROM THE TRANSPORT DEVICE ON-BOARD RECORDER}

\section{Introduction}

The today market of devices for establishing the position with using GPS technology (Global Positioning System) with NAVSTAR (NAVigation Signal Timing And Ranging) satellite navigation system technique [3], a lot of devices are freely available. Linking GPS with GSM (Global System for Communications Mobiles) technology permit increase operating possibilities of new type of telematic supported transport devices. At present we can send information about current GPS receiver position to the computer in real time. Specificity of transmitting data through GSM connections [6], on the example of the SMS message architecture [15] requires the translator enabling encoding the information about located object position. Today it is realized by NMEA algorithm [7]. Processing of acquired data [11] allow to increase safety and reliabilities of mobile means of transport. A mix devices combine a lot of different technology are continually develop $[1,10]$.

The paper is focusing on a method of using a type of the on-board device recorder for acquire alphanumeric sequence write on portable data carrier and the way of analysis possess data for needs of the safety and the reliability of mobile means of transport.

\section{Data acquired}

In paper $[8,9]$ was presented a method of the information transfer in the quasi real-time mode (on-line). It was realized with use of the GSM technology with the GPS module. It was a NV 7.0 code name device. At present a new GPS devices - code name NV 11 (NV devices are being shown on the Fig. 1) give additional options and possibilities. Geographic coordinates can be normal transmission with use of the GSM technology, but these devices can extra archiving posse's information on the memory stick. This information is complement about operating parameters concerning vehicle. Advantage of this solution is possibility connected specific exploitation parameters of means of transport with concrete geographic coordinates. 
a)

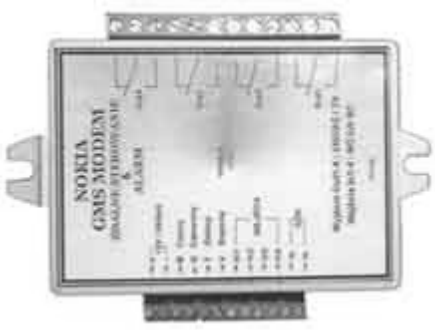

U

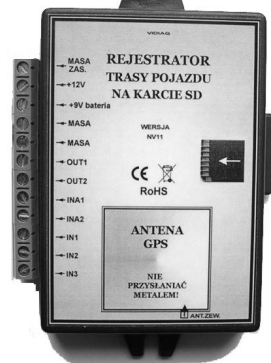

b)

Fig. 1. GPS/ GSM devices : a) GPS/GSM module type NV7.0, module type NV11 with the memory stick

b) GPS/GSM

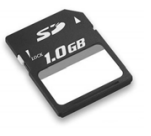

Recorded data contain the route of the vehicle. The route was being saved in the Source Map format in the *.trk - track file extension and *.wpt waypoint file extension. These files and these formats are compatible with the majority of digital maps (e.g. Cartall-Emapa Navigator). Preview of the *.trk file in the *.txt mode was shown on the Fig. 2.

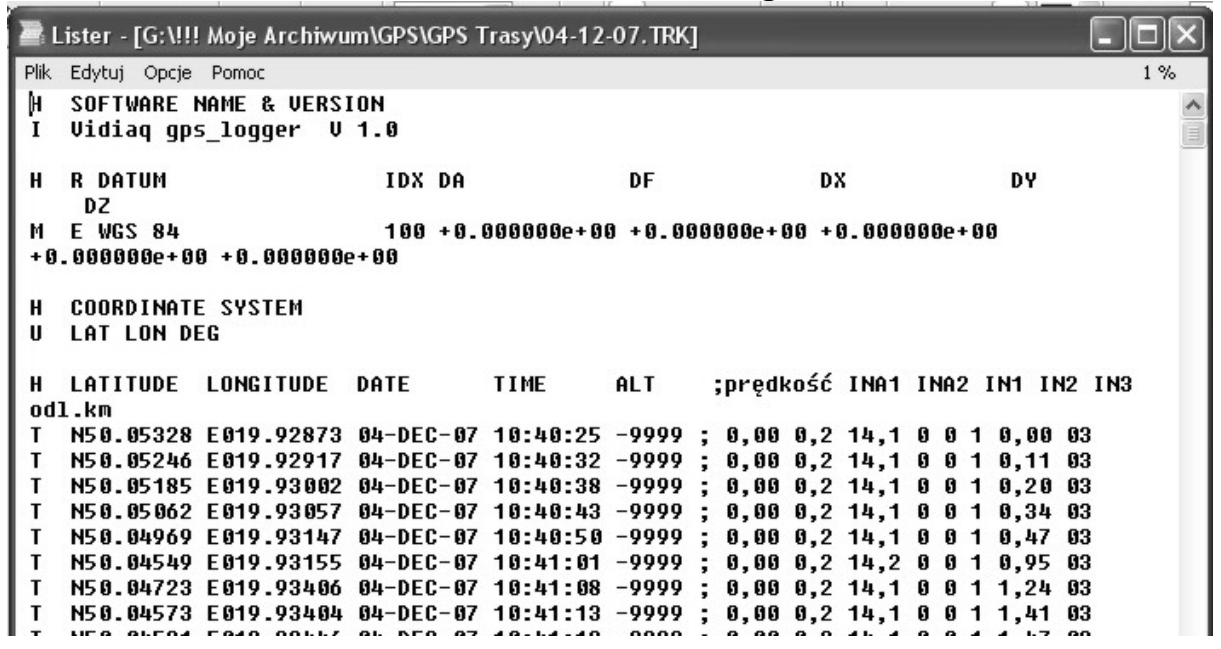

Fig. 2. Sample of TRK file display in TXT mode

The NV 11 recorder automatically saving *.trk type files in the format: $d d$-mm-rr.trk, additionally every file contains data concerning others parameters, so as:

- coordinates of longitude and latitude,

- date of the measurement,

- time of the measurement (in determined temporary intervals),

- non definable ALT value (program value stood),

- vehicle speed, 
- state of two analogue type inputs: INA1, INA2,

- state of three digital type inputs: IN1, IN2, IN3,

- number of visible satellites in the measurement moment.

Additionally the module generating on the memory card two kinds of other files. It is a Z.dat. this file doesn't contain essential data for the user and the Br_sygn.txt file [12], which is being created in the case when the function of the record is work but GPS receiver didn't establish the position.

\section{Data analysis and programme structure}

Some kind information posses from the *.trk file can be export to vector map computer software (e.g. Navigator Map of Poland 2007) [2] but some information will be lost. The Fig. 3. shown effect of export *.trk file in map source mode.

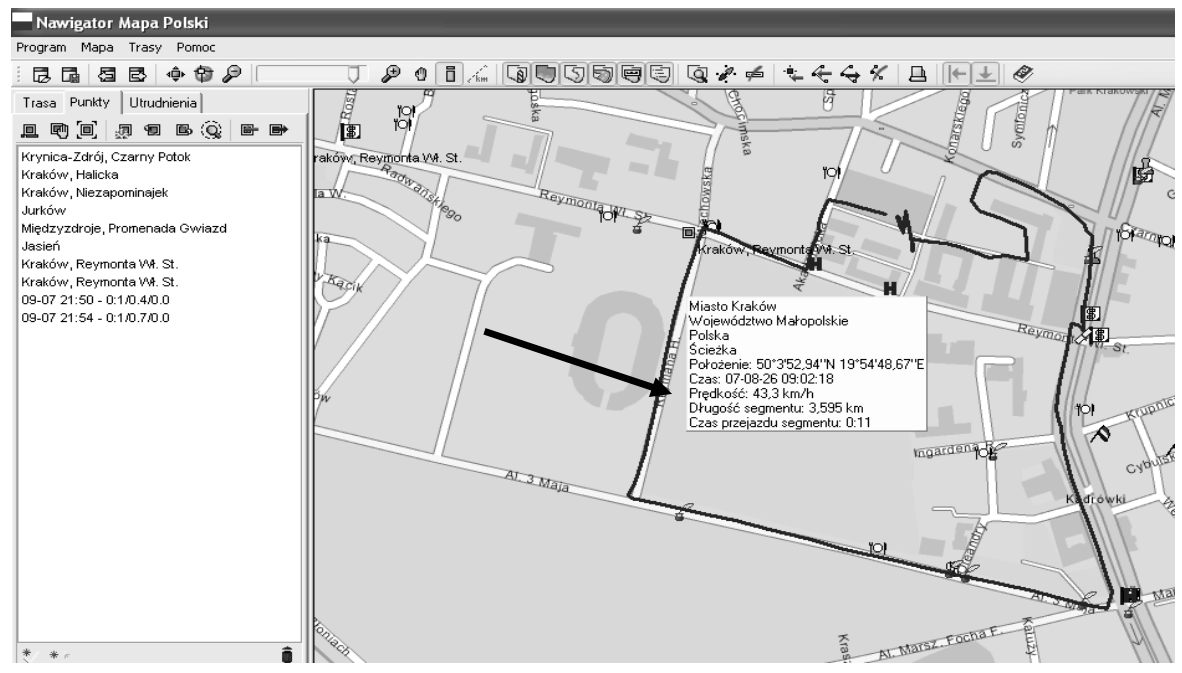

Fig. 3. TRK file presented graphically (route to path mode)

Fault of this kind data analysis/presentation is lots some information connected directly with GPS geographic coordinates. We have no information concerning vehicle exploitation parameters, get from analogue/digital inputs of the module. To the complete data analysis, was create a specialist software tool basing on the Visual Basic environment [13, $14]$.

Main structure of the program built several cooperating macros (Visual Basic language) works together and few additional instructions securing before main program overloading The maximum amounts to location which it is possible to fill with this environment is about 65000 lines [5]. 
The application enabling full analysis of the *.trk files. Fig. 4 shown first dialog screen from the ,analiza_trk" macros.

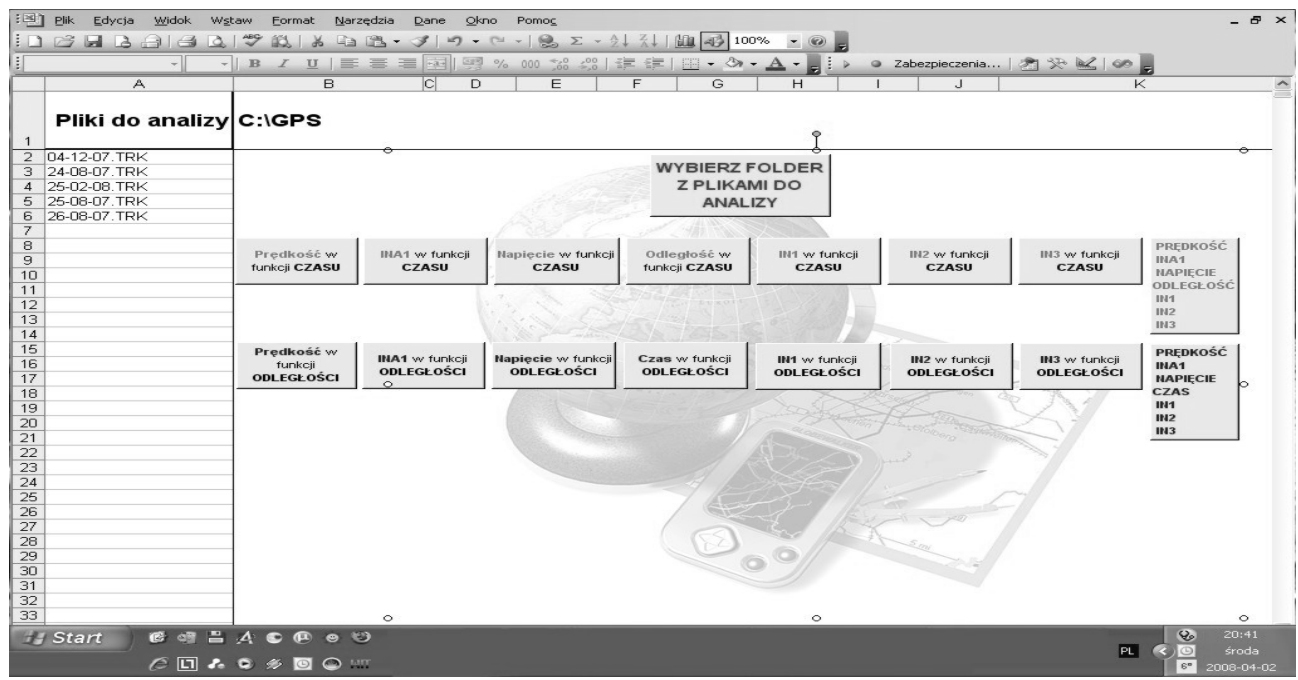

Fig. 4. First dialog screen from the analiza_trk

In figure 5 a block outline representing the algorithm of the effect of the program was presented for analysis of routes of means of transport. Five primary blocks are composing the presented algorithm [4] (shown on the Fig 5.):

- choice of the source/directory data to analysis,

- verification of the correctness of imported files,

- possibility of the export data into local memory for use for other application,

- utilize source code,

- generating the graphs.

Present application enables to create function of two freely chosen exploitation parameters of the whole data system. Figure 6. shown characteristic generated for the velocity of the vehicle in the time function. The figure 7. present characteristic generated for the same parameter (velocity) but in the distance function. Application architecture enable compare characteristic items of the track independent of chosen function. 


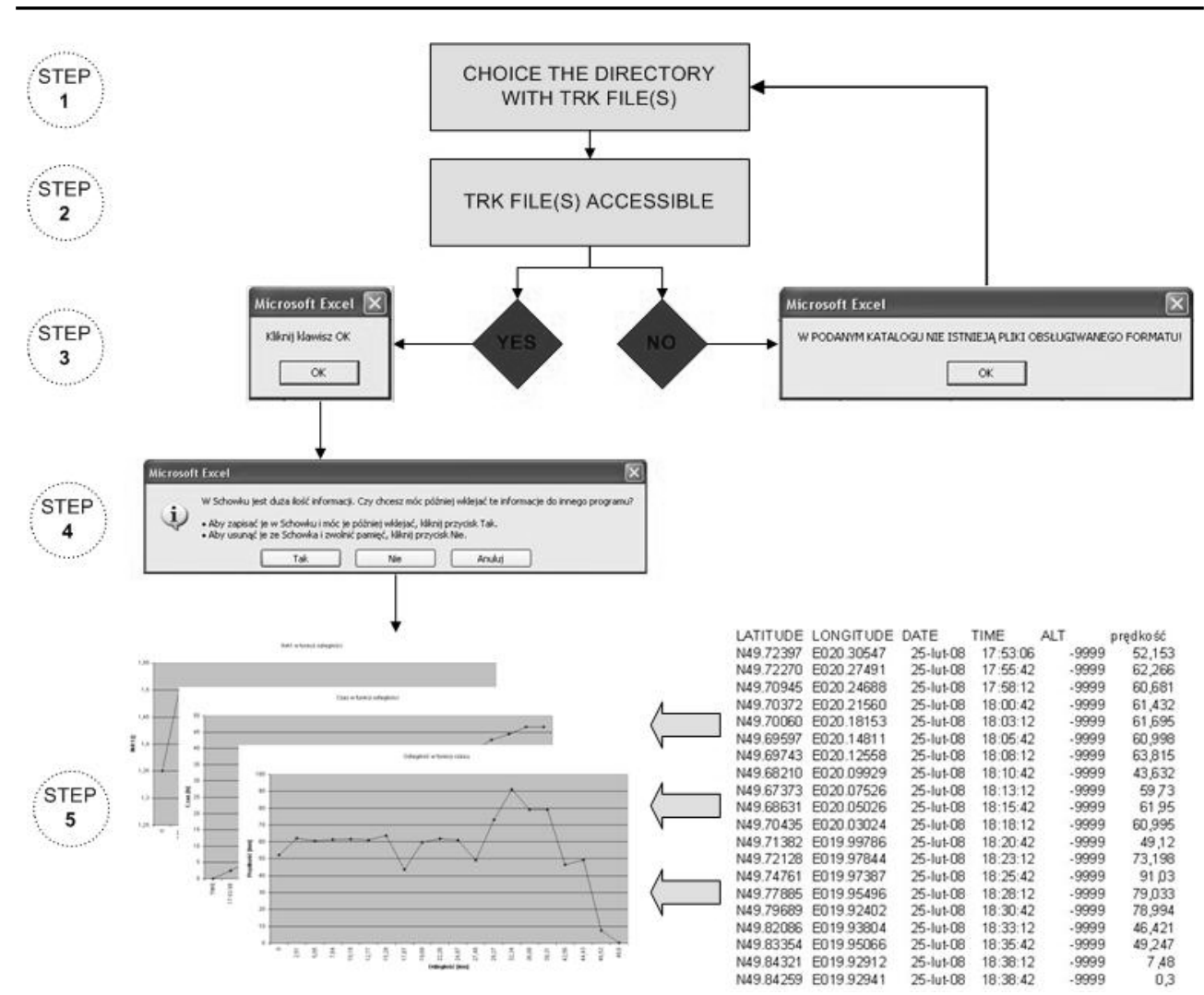

Fig. 5. Diagram box of main analiza_trk program algorithm

Prędkość wo funkcji czasu

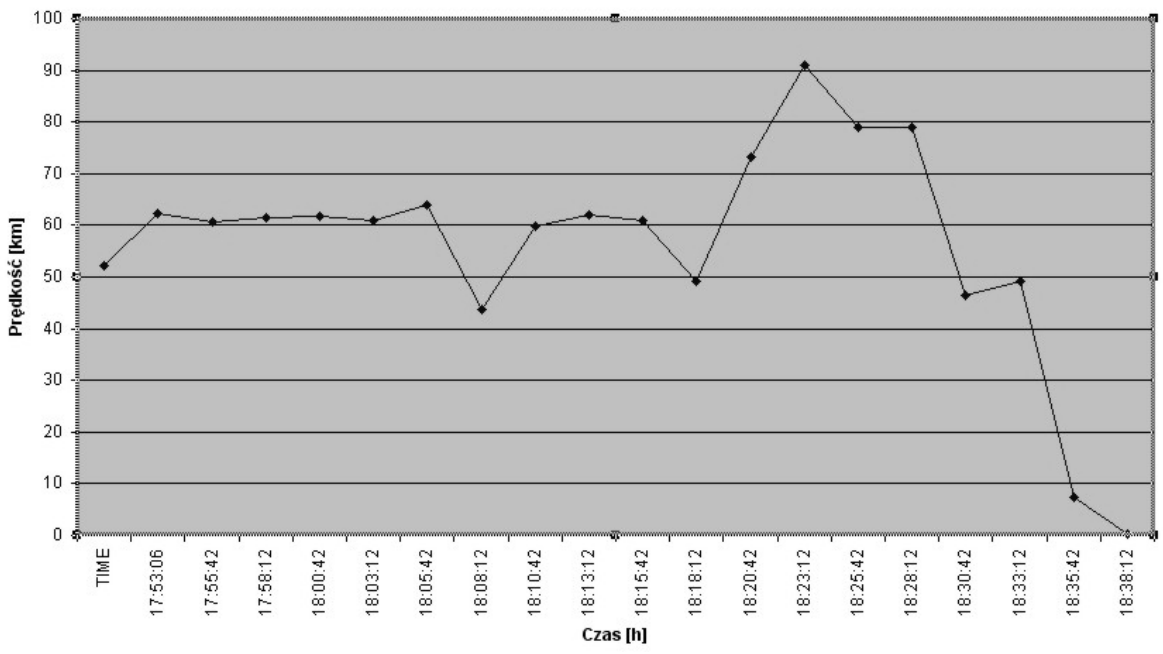

Fig. 6. Vehicle speed in time function 
Predkość w funkcji odległości

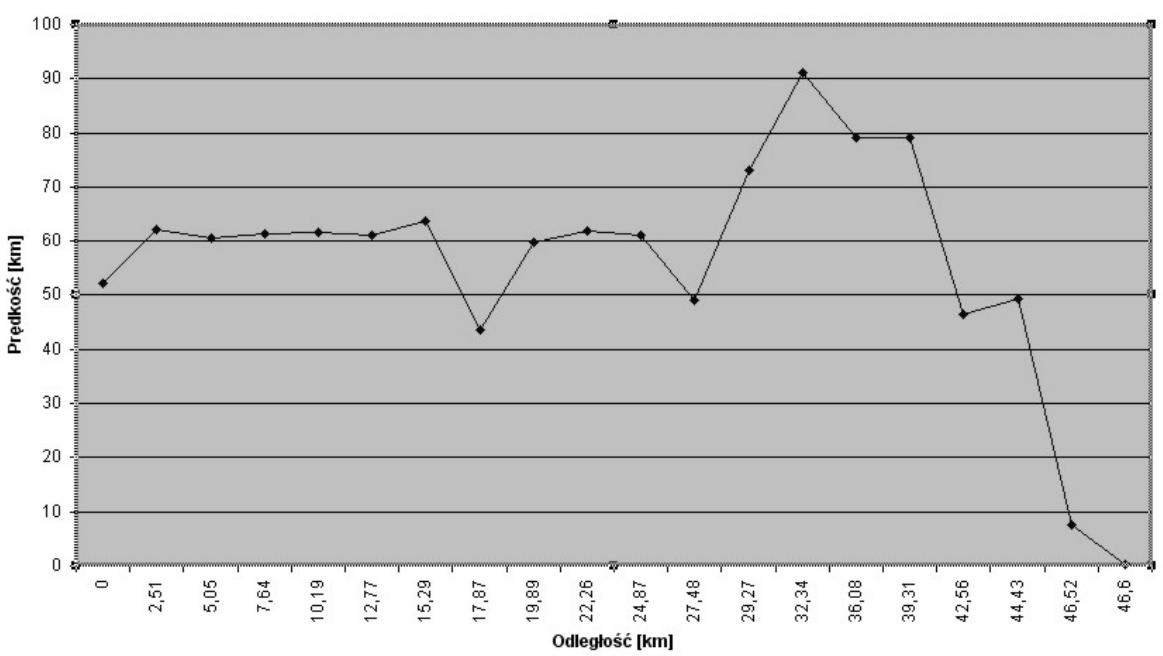

Fig. 7. Vehicle speed in distance function

\section{Conclusion}

The program described in the study serving for analysis of *.trk files is supplementing analyses, delivering the required information about the trajectory of the means of transport. This solution together with digital maps is multi functional tool for safety, reliability and exploitation of means of transport.

Presented solution is limited by program possibilities of application used for the data handling. Benefit of this solution is a fact of the popularity of used application and compatible application of the open-source code. The developed and improved satellite navigation effectively is supporting individual operators of all sorts' categories of the transport.

The research project is financed from the Polish Science budget for the years 2005 - 2008. 


\section{Bibliography}

1. Ardalan A., Awange J.L.: Compatibility of NMEA GGA with GPS receivers implementation. GPS Solution, v.3, no 3, p. 1-3, January 2000.

2. CARTALL: Mapa Polski 2007, Instrukcja obsługi programu.

3. Hofmann-Wellenhof B., Lichtenegger H., Collins J.: Global Positioning System: theory and practice. Springer, New York, 1997.

4. Jaszkiewicz A.: Inżynieria oprogramowania. Helion, Gliwice, 2007.

5. Kuciński K.: ABC Excela 2003. Edition 2000, 2003.

6. Mehrotra A.: GSM system engineering. Artech House, Boston, 1997.

7. SiRF: NMEA Reference Manual Revision 1.3. San Jose, January 2005.

8. Szpytko J., Hyla P.: The method of using the GPS device for distance assigning. Transport Problems, v. 2, no 2, Wydawnictwo Politechniki Śląskiej, Gliwice, 2007.

9. Szpytko J., Soja R.: Projekt uktadu nadawczo-odbiorczego GPS - GSM GPRS. Opracowanie wewnętrzne AGH, Kraków, 2006.

10. Szpytko J.: Ksztaltowanie procesu eksploatacji środków transportu bliskiego. Monografia, Biblioteka Problemów Eksploatacji, ITE, Kraków - Radom, 2004.

11. Van der Meer E., Hoffmann J. (Eds.): Knowledge aided information processing. North-Holland, Amsterdam, 1987.

12. VIDIAQ: Dane techniczne modutu NV11. Kraków, 2007.

13. Walkenbach J.: Excel 2003 Pl Programowanie w VBA - Vademecum Profesjonalisty. Helion, lipiec 2004.

14. Walkenbach J.: Microsoft Office Excel 2003 Bible. Wiley Publishing Inc., Indianapolis, 2003.

15. Yi-Bing Lin: GSM point-to-point Short Message Service. International Journal of Wireless Information Networks, v.4, no 4, p. 249-256, October 1997. 


\section{NARZĘDZIE DO PRZETWARZANIA DANYCH POZYSKANYCH Z REJESTRATORA POKLADOWEGO ŚRODKA TRANSPORTU}

\section{Wstęp}

$\mathrm{Na}$ rynku urządzeń ustalania pozycji z wykorzystaniem technologii GPS (ang. Global Positioning System) wykorzystującej system nawigacji satelitarnej NAVSTAR (ang. NAVigation Signal Timing And Ranging) [3], dostępne są urządzenia zwiększające możliwości operacyjne tych urządzeń. Unifikacja łącząca osiągnięcia technologii GSM (ang. Global System for Mobile Communications) i GPS służącego do przekazywania ustalonej pozycji środka transportu przez odbiornik do komputera w celu dalszego przetwarzania informacji o położeniu obiektu ciągle jest przedmiotem dynamicznego rozwoju $[1,10,11]$.

Specyfika przesyłania danych poprzez łącza GSM [6], na przykładzie architektury wiadomości SMS [15], wymaga translatora umożliwiającego jednoznaczne kodowanie informacji dotyczących pozycji lokalizowanego obiektu. Obecnie kodowanie jest realizowane poprzez standard NMEA [7].

Przedmiotem artykułu jest sposób użycia pokładowego e- urządzenia środka transportu do pozyskiwania informacji z procesu jego użytkowania (w postaci alfanumerycznego ciągu znaków zapisanych na przenośnym nośniku danych) oraz sposób analizy pozyskanych informacji dla potrzeb zapewnienia bezpieczeństwa i niezawodności struktury systemu transportowego.

\section{Pozyskiwanie danych}

$\mathrm{W}$ artykułach $[8,9]$ przedstawiono sposób przesyłu informacji w trybie quasi real-time (on-line) przy pomocy technologii GSM z wykorzystaniem modułu NV 7.0. Obecnie możliwa jest jednoczesna transmisja koordynatów $\mathrm{z}$ informacjami dodatkowymi (dotyczącymi przykładowo zmian parametrów eksploatacyjnych środka transportu) wraz $\mathrm{z}$ ich archiwizowaniem $\mathrm{w}$ pamięci wewnętrznej modułu. Funkcję zapewnia opracowany moduł NV11, który oprócz zapisu danych GPS, umożliwia także zapis wybranych parametrów eksploatacyjnych środka transportu. Zaletą rozwiązania jest pozyskiwanie różnej kategorii danych oraz ich odniesienia do współrzędnej geograficznej w sposób jednoznaczny 
opisujący przestrzeń roboczą urządzenia. $\mathrm{Na}$ rysunku 1 przedstawiono przykładowe moduły z serii „NV” różnych producentów.

a)

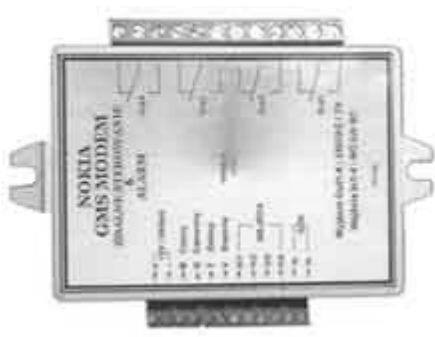

b)
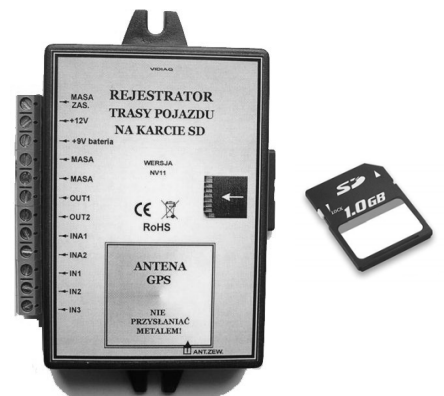

Rys. 1. Moduł GPS/ GSM : a) moduł GPS/GSM typ NV7.0,

b) moduł GPS/GSM typ NV11 z kartą pamięci

Rejestrowane dane dotyczące trasy środka transportu zapisywane są w formacie Map Source w pliku o rozszerzeniu *.trk (ang. track) oraz *.wpt (ang. waypoint). Pliki tych formatów są kompatybilne $\mathrm{z}$ większością map cyfrowych (np. Cartall-Emapa Nawigator). Podgląd zawartości pliku *.trk wyświetlanego $\mathrm{w}$ trybie tekstowym przez tak zwany lister środowiska MS Windows przedstawiono na rysunku 2.

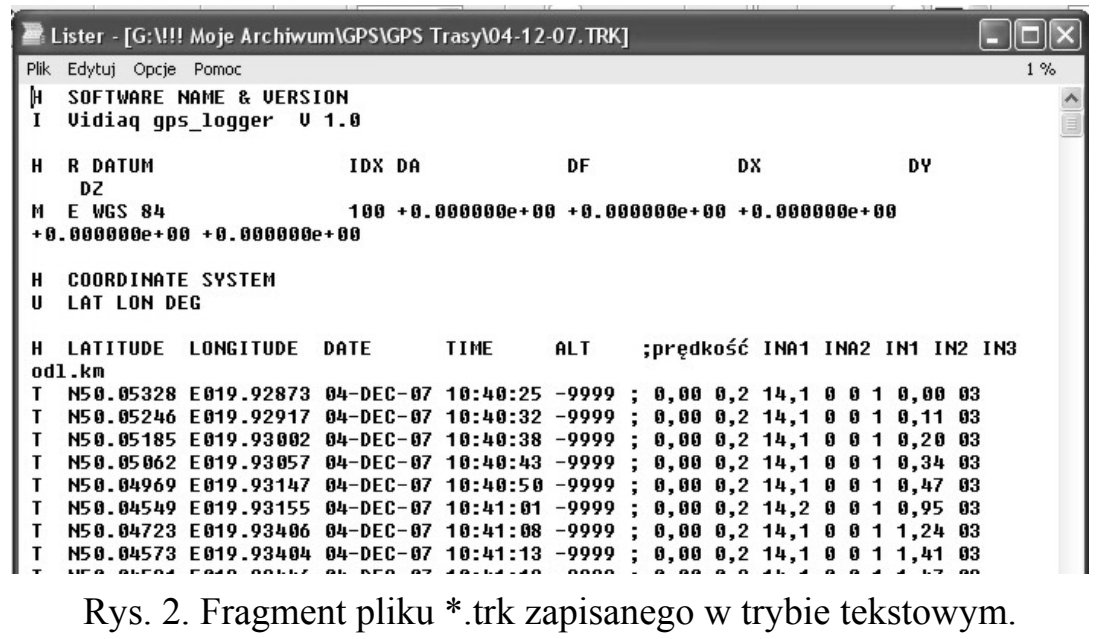

Plikom o rozszerzeniu *.trk moduł NV11 automatycznie nadawa jest nazwa w formacie: dd-mm-rr.trk. Dodatkowo każdy plik zawiera dodatkowe dane typu:

- współrzędne szerokości i długości geograficznej,

- data wykonania pomiaru,

- czas pomiaru (w określonych interwałach czasowych),

- wartość niedefiniowalną ALT (stała wartość programowa), 
- prędkość pojazdu,

- dwa wejścia analogowe typu: INA1, INA2,

- trzy wejścia cyfrowe typu: IN1, IN2, IN3,

- liczba satelitów widocznych w chwili pomiaru.

Dodatkowo na karcie pamięci moduł generuje plik wewnętrzny programu typu Z.dat, który nie zawiera istotnych danych dla użytkownika oraz plik typu Br_sygn.txt [12], który jest tworzony w przypadku gdy funkcja zapisu jest włączona, a odbiornik GPS nie ustalił jeszcze pozycji w przestrzeni roboczej.

\section{Analiza danych}

Dane wyjściowe z pliku *.trk można zaimportować do programów typu Map Source (np. Nawigator Mapa Polski 2007) [2]. Na rysunku 3 przedstawiono graficzny wynik importowanej mapy nałożonej $\mathrm{w}$ formie warstwy na mapę wektorową. Wadą takiej formy prezentacji danych jest brak możliwości pozyskania danych zintegrowanych bezpośrednio z danymi GPS połączonymi $\mathrm{z}$ współrzędnymi geograficznymi oraz danych dotyczących parametrów eksploatacyjnych urządzenia, uzyskanych z wejść analogowych lub/ i cyfrowych modułu. Dla potrzeb analizy danych, z wykorzystaniem środowiska programowania Visual Basic Excela [4, 13, 14], zbudowano aplikację umożliwiająca analizowanie plików typu *.trk. $\mathrm{Na}$ rysunku 4 przedstawiono ekran powitalny programu analiza_trk, który umożliwia analizowanie zmian dwóch dowolnie wybranych parametrów eksploatacyjnych charakteryzujących proces użytkowania badanego środka transportu.

Program zbudowano z wykorzystaniem zespołu współpracujących ze sobą makr wraz $\mathrm{z}$ instrukcjami napisanymi w języku Visual Basic, zabezpieczającymi przed przeciążeniem środowiska Excel 2003. Maksymalna ilość wierszy, które można wypełnić danymi wynosi około $65000[5]$. 


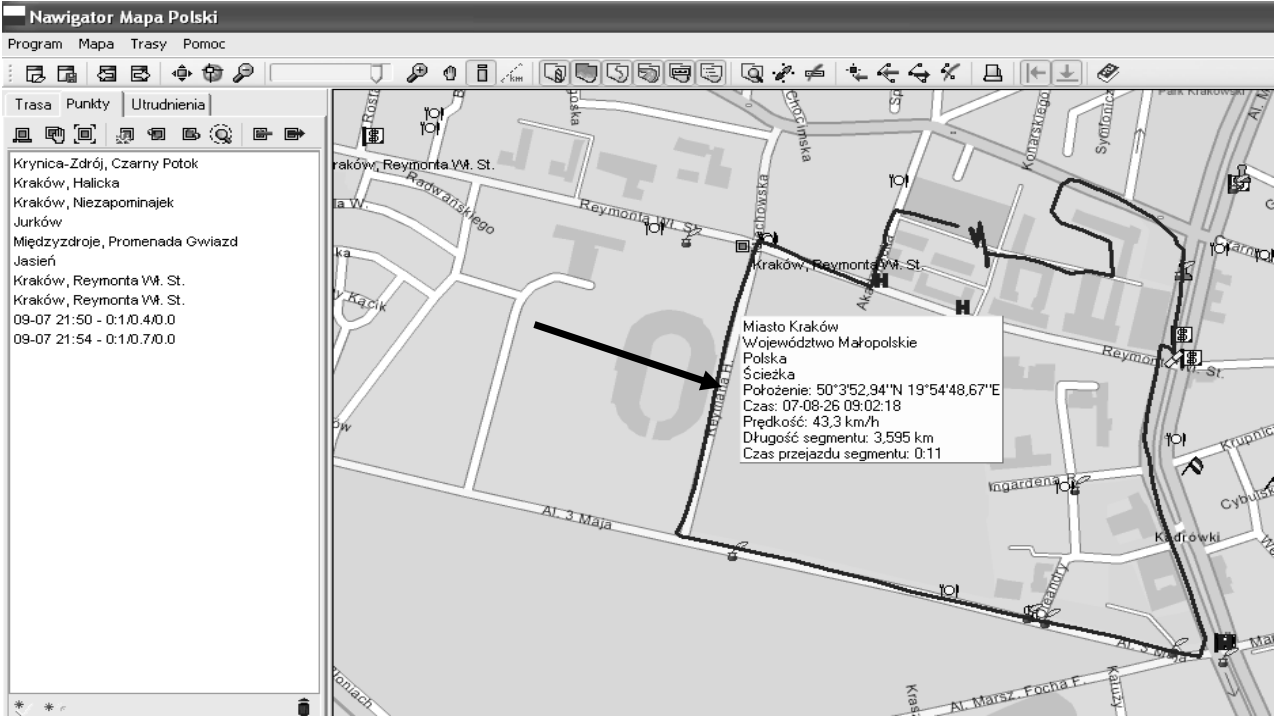

Rys. 3. Plik *.trk, nałożony na mapę wektorową w formie ścieżki.

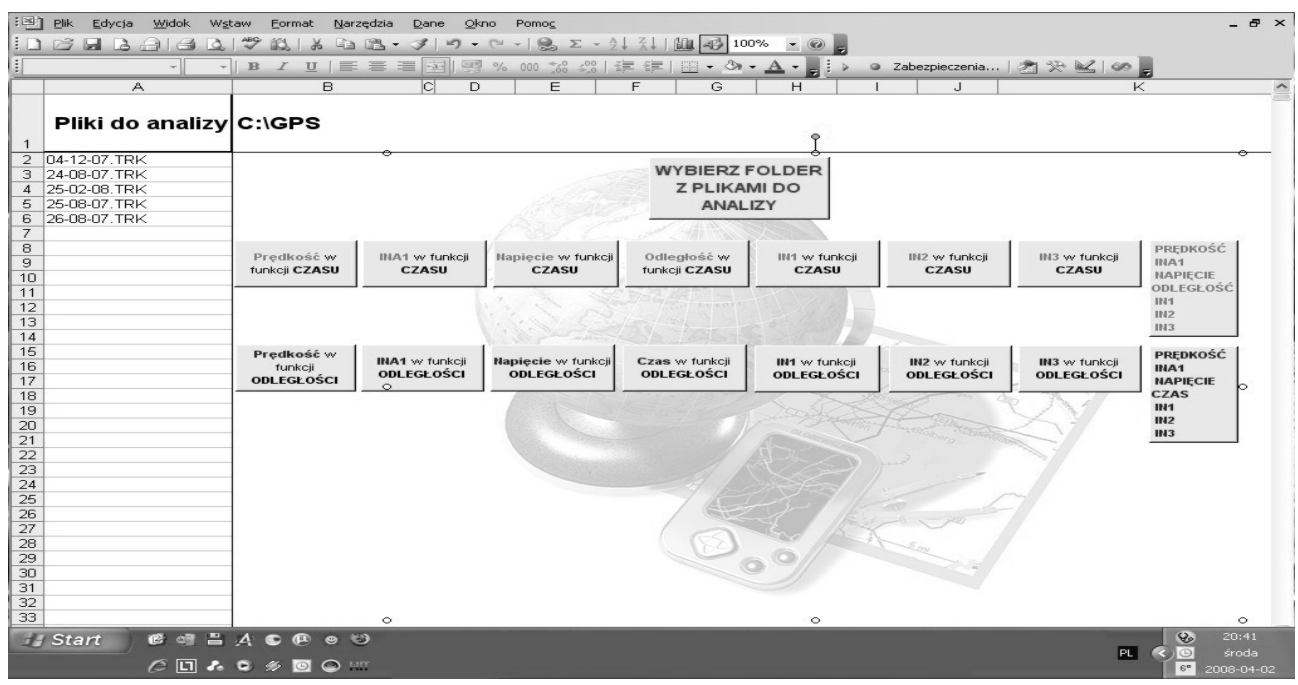

Rys. 4. Ekran powitalny programu analiza_trk.

Schemat blokowy algorytmu działania programu typu analiza_trk do analizy procesu użytkowania środka transportu przedstawiono na rysunku 5. Obejmuje on następujące kroki:

- wybór źródła eksportu danych,

- weryfikację prawidłowości importowanych plików,

- możliwość eksportu danych do pamięci podręcznej komputera, 
- wykorzystanie odpowiedniego fragmentu kodu źródłowego,

- generowanie wykresów.

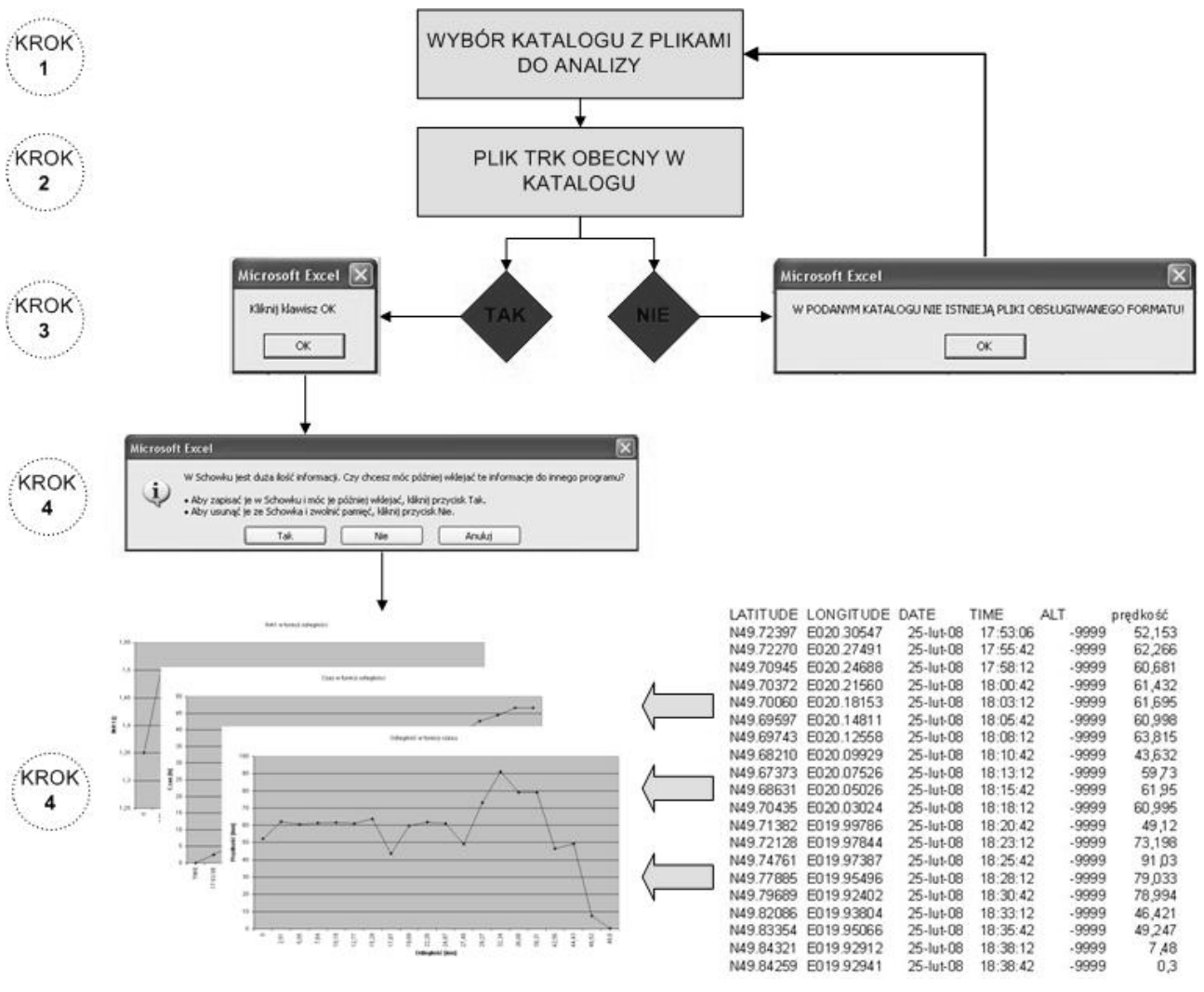

Rys. 5. Schemat blokowy algorytmu programu analiza_trk

Opracowana wersja programu umożliwia analizowanie w funkcji czasu wybranych parametrów eksploatacyjnych środka transportu, zapisanych w pliku typu *.trk. Na rysunku 6 przedstawiono charakterystykę zmian prędkości środka transportu $\mathrm{w}$ funkcji czasu, natomiast na rysunku 7 w funkcji zmian odległości (przebytej drogi). 


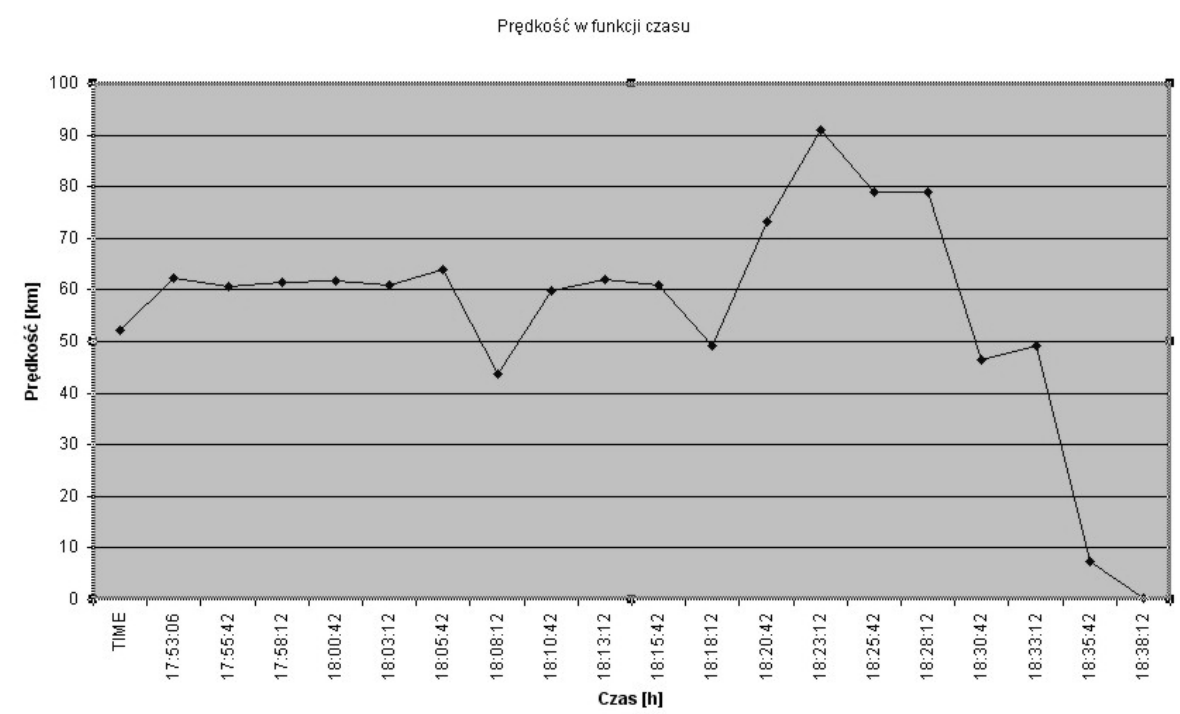

Rys. 6. Przykładowy wykres prędkości w funkcji czasu dla środka transportu

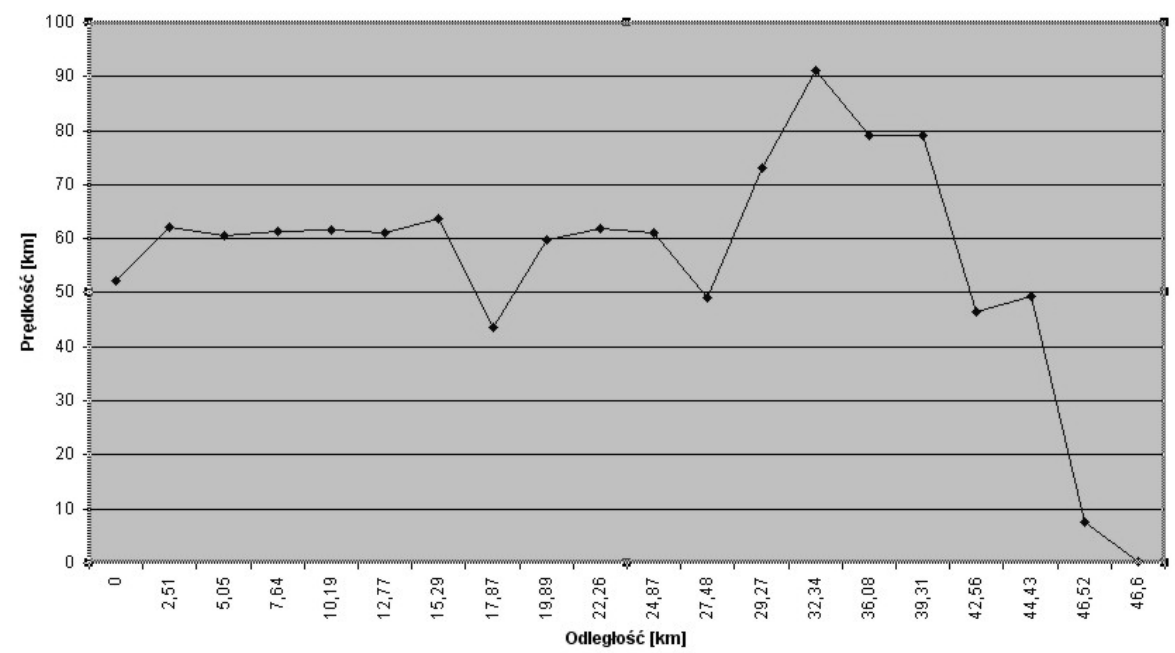

Rys. 7. Przykładowy wykres prędkości w funkcji odległości dla środka transportu

\section{Uwagi końcowe}

Opracowany program do analizy plików typu *.trk uzupełnia mapy cyfrowe środków transportu, dostarczając wymaganych informacji $\mathrm{w}$ zakresie trajektorii ruchu środka transportu wraz z jej punktami charakterystycznymi oraz zmian obserwowanych parametrów eksploatacyjnych urządzenia. 
Przedstawione rozwiązanie jest ograniczone możliwościami programowymi wykorzystanej do obróbki danych aplikacji. Na korzyść tego rozwiązania przemawia fakt popularności wykorzystanej aplikacji oraz rozwiązań kompatybilnych typu open-source. Rozwijana i doskonalona nawigacja satelitarna skutecznie wspomaga indywidualnych operatorów różnych modów transportu.

Praca naukowa finansowana ze środków budżetowych na naukę w latach 2005 2008 jako projekt badawczy.

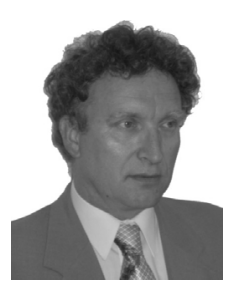

Prof. dr hab. inż. Szpytko Janusz, AGH University of Science and Technology, Faculty of Mechanical Engineering and Robotics. Specialist in designing and exploitation of transport systems and devices, automatics, safety and reliability, monitoring and diagnostics, decision making systems, telematics. Author or co-author of more than 320 publications, both in Polish and English. Member of: STST KT PAN, TC IFAC, SEFI, ISPE, PTD, PTB, PSRA, ISA, SITPH and others. Visiting professor at the universities in: UK, France, Canada, Italy, Greece, Canada, Laos. Coordinator and member of several R\&D projects both national and international. Organizer and member of several scientific and programme committees of international and national conferences and symposiums

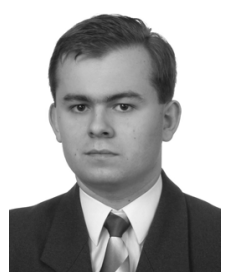

Mgr inż. Hyla Pawel, AGH University of Science and Technology, Faculty of Mechanical Engineering and Robotics. Specialization: engineering, GPS technology, object tracking, telematics. Several publications in field. 
